\title{
Efektifitas Pembelajaran Berbasis Inquiry Melalui Implementasi Modeling Instruction pada Materi Alat Optik
}

\author{
Soekarman \\ SMAN 2 Donggo, Kabupaten Bima - Provinsi NTB \\ *Corresponding Author. Email: soekarmanman1981@gmail.com
}

\begin{abstract}
This study aims to analyze inquiry-based learning through the implementation of modeling instruction on optical instrument materials. This research method used quantitative descriptive research. The subjects of this study were students of class XI IPA SMAN 2 Donggo. The collection technique includes observation, literature review, questionnaire, test and documentation. The data obtained will be analyzed descriptively quantitatively, among the research data to be analyzed are: student activities, learning outcomes, and student responses to ongoing learning. The results of this study include: 1) Student activity obtained a score of $74.58 \%$ or good category, 2) Inquiry learning with Modeling Instruction on optical instrument material can actually improve students' understanding with an $\mathrm{N}$-gain score of 1.3 points or very high category. high, 3) Student responses to learning obtained a score of $84.37 \%$ or very interesting category. Based on the results of the study, it was found that through Inquiry learning with Modeling Instruction on Optical Instruments material, it can be used as an alternative to improve the quality of learning in class, especially in Physics subjects.
\end{abstract}

\begin{abstract}
Abstrak: Penelitian ini bertujuan untuk menganalisis pembelajaran berbasis inquiry melalui implementasi modeling instruction pada materi alat optik. Metode penelitian ini menggunkan penelitian deskriptif kuantitatif. Subjek penelitian ini adalah siswa kelas XI IPA SMAN 2 Donggo. Teknik pengumpulan meliputi pengamatan, literature review, angket, tes dan dokumentasi. Data yang diperoleh akan dianalisis secara deskriptif kuantitatif, diantara data penelitian yang akan dianalisis berupa: aktifitas siswa, hasil belajar, dan respon siswa terhadap pembelajaran yang berlangsung. Hasil penelitian ini antara lain: 1) Keaktifan siswa diperoleh skor sebesar 74,58\% atau kategori baik, 2) Pembelajaran Inquiry dengan Modelling Instruction pada materi alat optik ternyata dapat meningkatkan pemahaman siswa dengan skor $N$ gain sebesar 1,3 point atau kategori sangat tinggi, 3) Respon siswa terhadap pembelajaran diperoleh skor $84,37 \%$ atau kategori sangat menarik. Berdasarkan hasil penelitian yang diperoleh bahwa melalui pembelajaran Inquiry dengan Modelling Instruction Pada materi Alat Optik, dapat dijadikan sebagai salah satu alternatif memperbaiki kualitas pembelajaran dikelas khususnya pada mata pelajaran Fisika.
\end{abstract}

How to Cite: Soekarman, S. (2021). Efektifitas Pembelajaran Berbasis Inquiry Melalui Implementasi Modeling Instruction pada Materi Alat Optik. Jurnal Paedagogy, 8(4), 545-551. doi:https://doi.org/10.33394/jp.v8i4.4129

https://doi.org/10.33394/jp.v8i4.4129

This is an open-access article under the CC-BY-SA License.

\author{
Article History \\ Received: $10-08-2021$ \\ Revised: 16-08-2021 \\ Accepted: 10-09-2021 \\ Published: 05-10-2021
}

\section{Key Words: \\ Inquiry, Modeling \\ Instruction, Optical.}

\section{Sejarah Artikel \\ Diterima: 10-08-2021 \\ Direvisi: 16-08-2021 \\ Disetujui: 10-09-2021 \\ Diterbitkan: 05-10-2021}

\section{Kata Kunci:}

Inquiry, Modeling Instruction, Alat Optik.

\section{Pendahuluan}

Fisika sebagai salah satu mata pelajaran IPA memiliki karakteristik sangat komplek, luas, dan setiap saat selalu mengalami perkembangan. Sementara sebagian peserta didik juga menganggap bahwa mata pelajaran Fisika itu ribet dan membosankan, karena alasannya penuh dengan Hitungan dengan Rumus, sangat membutuhkan energi untuk membaca bahkan mengahfalkannya. Kesalahpahaman peserta didik terhadap mata pelajaran Fisika ini, diperparah lagi dengan kurang kreatif dan inovatifnya guru dalam mengelola proses 
pembelajaran, membuat respon, keaktifan, dan motivasi belajar peserta didik sangat rendah. Tidak adanya cipta kondisi pengalaman langsung bagi peserta didik yang di berikan oleh guru dalam proses pembelajaran, juga menyebabkan hasil dari yang diharapkan tidak maksimal dan tidak bermakna (Soekarman, 2021).

Salah satu alternatif yang di coba sapat dilakukan oleh guru untuk meningkatkan kualitas pembelajaran adalah dengan mengimplementasikan Modelling Instruction hasil pelatihan di Nagoya University dan memadukannya dengan pembelajaran interaktif melalui pendekatan Inquiry. Model pembelajaran inquiry adalah rangkaian kegiatan pembelajaran yang menekankan pada proses berpikir kritis dan analisis untuk mencari dan menemukan sendiri jawaban dari suatu masalah yang dipertanyakan (Sanjaya, 2006; Harni, 2021; Nasiroh, 2021). Perpaduan dua hal ini diharapkan dapat membantu anak dalam memahami materi Fisika yang sulit, bersifat abstrak menjadi materi yang mudah dan bermakna. Pembelajaran inquiry menempatkan siswa sebagai subjek belajar, siswa tidak hanya menerima pembelajaran saja, melainkan dapat menelaah, memilah dan memberikan tanggapan atas materi pelajaran yang diberikan (Sanita \& Anugraheni, 2020; Nurkhasanah, 2019; Nahak \& Bulu, 2020).

Dengan pembelajaran berbasis inquiry dan implementasi Modelling Instruction selama proses pembelajaran, peserta didik dapa menggunakan banyak indera untuk melakukan pendataan, penyelidikan, sehingga mudah menerima dan menyerap sebuah ilmu sehingga hasilnya lebih optimal. Hal ini senada dengan pernyataan Dr. Vernon bahwa semakin banyak indera yang dilibatkan, pelajaran semakin bermakna (Potter, 2010). Modeling Instruction (MI) merupakan sebuah pendekatan yang membelajarkan inkuiri yang secara terbimbing kepada siswa untuk menemukan konsep, menguji, serta menggunakannya sebagai sebuah model hubungan secara fisis. MI memiliki siklus yang merupakan tahapan pengembangan yakni: membuat model, mengembangkan, mengelaborasi model, serta mengaplikasikan model (Megowan-Romanowicz, 2016).

Dalam kelas, guru biasanya mengawali dengan permasalahan dan bukan pembelajaran berbasis materi, kemudian siswa dibagi dalam kelompok kecil untuk merencanakan dan mengumpulkan data, menganalisis, serta sharing hasil analisis melalui whiteboard. Hasil analisis dapat dalam bentuk gambar, bagan, grafik dan atau teks. Proses sharing dilakukan oleh tiap kelompok dalam kelas, bersama dengan guru. Tahap selanjutnya adalah diskusi terhadap hasil yang didapat dan mengidentifikasi hubungan antar komponen yang terkait dan membuat prediksi hasil yang akan didapatkan (berbasis bukti dan argument) Pendekatan ini terbukti dari berbagai penelitian dapat meningkatkan pengetahuan konseptual yang dimiliki siswa secara signifikan melalui prosesnya.

Berdasarkan fakta yang ditemukan selama pembelajaran selama ini dan penjabaran tentang Modelling Instruction (MI), dengan pembelajaran berbasis inquiry dan implementasi Modelling Instruction selama proses pembelajaran, diharapkan dapat meningkatkan keterampilan kolaborasi dan komunikasi yang dimiliki oleh siswa. Dengan modelling instruction ini juga diharapkan dapat memberikan salah satu alternatif dalam pemecahan masalah, demi perbaikan kualitas pendidik, serta menciptakan suasana belajar di dalam kelas menjadi lebih menarik, interaktif dan bermakna.

Adapun tujuan penelitian ini adalah untuk menganalisis aktivitas siswa, tingkat pemahaman, dan respon siswa melalui pembelajaran berbasis inquiry dengan modelling instruction pada materi alat optik. 


\section{Metode Penelitian}

Metode yang digunakan dalam penelitian ini bersifat diskriptif kuantitatif melalui quasi eksperimen. Subjek penelitian ini adalah guru sebagai peneliti, dibantu observer, dan siswa kelas XI IPA SMAN 2 Donggo, Kabupaten Bima. Sedangkan subjek materi adalah kompetensi dasar mata pelajaran Fisika K-13 kelas X IPA semester genap, yaitu pada materi Alat Optik. Penelitian ini menggunakan 5 teknik pengumpulan data, yaitu: 1) Pengamatan (observasi), 2) Penelusuran literatur (literature review), 3) Lembar angket (quisioner), 4) Tes dan, 5) Dokumentasi. Data yang diperoleh akan dianalisis secara deskriptif dan kuantitatif, diantara data penelitian yang akan dianalisis berupa : aktifitas siswa, hasil belajar, dan respon siswa terhadap pembelajaran yang berlangsung. Keaktifan pembelajaran siswa dalam mengikuti proses belajar sebagai berikut:

Keterangan

$$
P K=\frac{S}{S N \times S M} \times 100 \%
$$

$\mathrm{Pk}=$ Persentase keaktifan siswa

$\mathrm{S}=$ Jumlah skor perolehan

SN = Jumlah siswa

$\mathrm{SM}=$ Skor Maksimal

Kriteria persentase aktivitas belajar siswa dalam proses pembelajaran pada tabel berikut ini.

Tabel 1. Kriteria Persentase Aktivitas Belajar Siswa

\begin{tabular}{|l|l|}
\hline Persentase & Kriteria \\
\hline $85 \%-100 \%$ & Sangat Tinggi \\
\hline $70 \%-84 \%$ & Tinggi \\
\hline $50 \%-69 \%$ & Sedang \\
\hline $0 \%-49 \%$ & Rendah \\
\hline
\end{tabular}

Analisis peningkatan hasil belajar yang berasal dari nilai pretest dan postest dapat menggunakan skor gain yang dinormalisasi. Gain yang dinormalisasi dapat dihitung menggunakan rumus gain score ternormalisasi dengan rumus sebagai berikut (Hake, 1999).

$$
\langle\mathbf{g}\rangle=\frac{(\% 6<f>-\psi \%<S i>)}{\left(100 \%-\psi_{0}<S 1>\right)}
$$

Keterangan

$S_{f} \quad=$ Skor postest (final score)

$S_{i} \quad=$ Skor prestest (initial score)

$100 \%=$ Konstanta

Tabel 2. Kategori N-gain Ternormalisasi

\begin{tabular}{|c|c|}
\hline Skor $\mathbf{N}-$ Gain & Kriteria Normalized Gain \\
\hline N-Gain $>0,70$ & Tinggi \\
\hline $0,30 \leq \mathbf{N}$-Gain $\leq \mathbf{0 , 7 0}$ & Sedang \\
\hline N-Gain $<0,30$ & Rendah \\
\hline
\end{tabular}

Analisis angket respon siswa ini dilakukan dengan menghitung rata-rata skor respon siswa dengan rumus sebagai berikut: Respon siswa $=$ 


\section{Jumlah skor diperoleh dari respon siswa Jumlah skor total respon siswu}

Hasil perhitungan dari respon siswa tersebut kemudian di analisis menggunakan criteria penilaian seusai dengan kriteria penilaian lembar respon siswa sebagai berikut:

Tabel 3. Kriteria Penilaian Lembar Angket Respon

\begin{tabular}{|c|c|c|}
\hline No & Kriteria Penilaian & Persentase \\
\hline 1 & Sangat Positif (SP) & $75,6 \% \leq \mathrm{x} \leq 100 \%$ \\
\hline 2 & Positif (P) & $50,6 \% \leq \mathrm{x} \leq 75,5 \%$ \\
\hline 3 & Negatif (N) & $25,6 \% \leq \mathrm{x} \leq 50,5 \%$ \\
\hline 4 & Sangat Negatif (SN) & $0 \% \leq \mathrm{x} \leq 25,5 \%$ \\
\hline
\end{tabular}

\section{Hasil Penelitian dan Pembahasan}

Penemuan permasalahan pembelajaran sebelumnya antara lain ; (1) Sebagian besar guru masih menerapkan pembelajaran yang konvensional dengan metode ceramah Tanya jawab, pemberian tugas, (2) Minat dan motivasi guru dalam berinovasi yang masih rendah, (3) Tingkat aktifitas dan motivasi siswa dalam pembelajaran Fisika di kelas masih rendah, (4) Hasil pencapaian kompetensi siswa yang diharapkan guru setelah belajar masih kurang memuaskan, (5) Respon siswa dalam mengikuti pembelajaran Fisika yang guru selama ini terapkan kategori cukup menarik, (5) Kesalahfahaman siswa terhadap materi pelajaran Fisika, seperti ; rumit, sangat komplek, banyak bahasa lain, susah menghafalnya, serta bukan ilmu pasti murni.

Berdasarkan temuan masalah yang terjadi pada guru dan siswa dikelas selama proses pembelajaran sebelumnya, maka tindakan cepat yang harus segera dilakukan oleh guru adalah dengan menerapkan pendekatan pembelajaran menarik dan interaktif tertentu yang sudah teruji keberhasilanya guna menjawab dan mengatasi masalah yang ada. Hal ini senada yang dinayatakan Abdul Majid (2014) bahwa dengan pembelajaran yang interaktif peserta didik belajar mengajukan pertanyaan, mencoba merumuskan pertanyaan, dan mencoba menemukan jawaban terhadap pertanyaan sendiri dengan melakukan observasi atau pengamatan. Dengan cara seperti itu, lalu peserta didik menjadi kritis dan aktif belajar. Solusi pemecahan masalah yang dilakukan adalah dengan mengkombinasikan pembelajaran berbasis inquiry dan pendekatan Modelling instruction yang sesuai dengan topik yang diajarkan. Tahapan-tahapan dalam pemecahan masalah pembelajaran di uraikan sebagai berikut;

Tabel 4. Kriteria Dalam Merencanakan Kegiatan Pembelajaran Berbasis Inquiry Dengan Pendekatan Modelling Instruction

\begin{tabular}{|l|l|l|}
\hline \multicolumn{1}{|c|}{ Tahap Kegiatan } & \multicolumn{1}{c|}{ Aktifitas Kegiatan } & \multicolumn{1}{c|}{ Indikator } \\
\hline Menganalisis & $\begin{array}{l}\text { Menganalisis dengan melakukan } \\
\text { kegiatan observasi terlebih dahulu } \\
\text { terhadap permasalahan yang } \\
\text { muncul dalam pembelajaran sehari- } \\
\text { hari yang akan dicoba untuk } \\
\text { diperbaiki. }\end{array}$ & $\begin{array}{l}\text { Ditemukan permasalahan } \\
\text { pembelajaran dikelas baik } \\
\text { dari pihak guru dan sisa }\end{array}$ \\
\hline Merencanakan & Merencanakan secara sistematik & Terpilihnya model, \\
\hline
\end{tabular}




\begin{tabular}{|l|l|l|}
\hline \multicolumn{1}{|c|}{ Tahap Kegiatan } & \multicolumn{1}{|c|}{ Aktifitas Kegiatan } & \multicolumn{1}{c|}{ Indikator } \\
\hline Mengembangkan & $\begin{array}{l}\text { proses pembelajaran berbasis } \\
\text { inquiry dan perangkatnya, termasuk } \\
\text { memilih alat bantu belajarnya yang } \\
\text { akan digunakan }\end{array}$ & $\begin{array}{l}\text { metode, strategi, } \\
\text { pendekatan, serta media } \\
\text { yang digunakan dalam } \\
\text { pembelajaran }\end{array}$ \\
\hline Mengimplementasikan & $\begin{array}{l}\text { Mengembangkan perangkat } \\
\text { pembelajaran (materi/bahan, media } \\
\text { dan alat) yang diperlukan dalam } \\
\text { pembelajaran. Berdasarkan saran } \\
\text { masukan ahli atau validator (rekan } \\
\text { sejawat sesame guru Fisika) }\end{array}$ & $\begin{array}{l}\text { Dihasilkan produk } \\
\text { perangkat pembelajaran } \\
\text { berbasis Inquiry dan } \\
\text { pendekatan pembelajaran } \\
\text { yang akan digunakan }\end{array}$ \\
\hline $\begin{array}{l}\text { Melaksanakan pembelajaran } \\
\text { berbasis Inquiry dengan } \\
\text { mengimplementasikan pendekatan } \\
\text { pembelajaran pada kelas dan topic } \\
\text { yang telah direncanakan, serta } \\
\text { mengamati proses pembelajaran } \\
\text { yang berlangsung }\end{array}$ & $\begin{array}{l}\text { Terlaksananya } \\
\text { pembelajaran berbasis } \\
\text { inquiry dengan } \\
\text { pendekatan pembelajaran } \\
\text { Modelling instruction }\end{array}$ \\
\hline Mengevaluasi & $\begin{array}{l}\text { Mengevaluasi dampak dari } \\
\text { penerapan pembelajaran berbasis } \\
\text { inquaiy dengan pendekatan } \\
\text { pembelajaran Modelling instruction } \\
\text { dengan mengukur ketercapaian } \\
\text { dengan instrumen yang telah } \\
\text { ditentukan }\end{array}$ & $\begin{array}{l}\text { Mendapatkan data } \\
\text { efektifitas dan respon } \\
\text { siswa serta guru dengan } \\
\text { pembelajaran yang telah } \\
\text { berlangsung }\end{array}$ \\
\hline pengang
\end{tabular}

Dalam penelitian ini bahwa pendekatan Modelling Instruction untuk pembelajaran Fisika belum pernah di implementasikan di sekolah. Banyaknya keluhan para guru dalam kelompok MGMP Fisika, tentang bagaiamana sulitnya membuat anak lebih memahami materi Fisika, termasuk materi Alat Optik didalamnya.

Hasil observasi selama beberapa tahun terakhir juga menunjukan bahwa peserta didik ternyata lebih aktif, mudah mengingat, dan timbul respon sangat baik, jika pembelajaran dikelas tersebut mengunakan beberapa media bantu ajar dan pendekatan yang tepat. Pendekatan atau model pembelajaran yang dikemas menarik dan interaktif membuat anak nyaman dan betah dalam pembelajaranya. Hal ini yang mendasari saya menerapkan pembelajaran dengan pendekatan Modelling instruction. Karena dengan pemilihan pendekatan belajar yang tepat, ternyata dapat memberikan pengalaman langsung pada anak, dimana dalam tidak hanya belajar dari membaca, mendengar, tapi juga diberi ruang untuk anak berkreasi, berkomonukasi, interactif dan terjadi proses kolaboratif, sehingga pembelajaran lebih bermakna. Implementasi pembelajaran berbasis Inquiry dengan pendekatan Modelling Instruction pada pembelajaran di kelas, adalah sebagi upaya perbaikan kualitas pembelajaran terutama pada materi Alat Optik, dan juga penerapan salah satu praktik baik dalam pembelajaran hasil pelatihan di Nagoya University di Jepang.

Hasil yang telah dicapai dari pelaksanaan pembelajaran yakni; (1) Keaktifan siswa dengan pembalajaran berbasis inquiry pada Alat Optik manusia melalui pendekatan Modelling instruction diperoleh scor sebesar 74,58 \% atau kategori baik, (2) Pembalajaran berbasis inquiry pada Alat Optik manusia melalui pendekatan modelling instruction ternyata 
dapat meningkatkan pemahaman siswa dengan scor $\mathrm{N}$-gain sebesar 1,3 point atau kategori sangat tinggi, (3) Respon siswa terhadap pembalajaran berbasis inquiry pada Alat Optik manusia melalui pendekatan modelling instruction diperoleh scor 82,29\% atau kategori sangat menarik bagi siswa.

\section{Kesimpulan}

Kesimpulan yang diperoleh dari penelitian ini adalah; (1) Pembelajaran berbasis inquiry melalui pendekatan Modelling instruction dapat meningkatkan aktifitas belajar siswa, (2) Pembelajaran berbasis inquiry modifikasi melalui pendekatan Modelling instruction sangat efektif karena dapat meningkatkan pemahaman siswa terhadap materi Alat Optik, dan (3) Respon siswa setelah pembelajaran berbasis inquiry melalui pendekatan Modelling instruction sangat tinggi atau kategori sangat menarik bagi siswa.

\section{Saran}

Saran bagi bagi guru; (1) Untuk mengimplementasikan Pembelajaran melalui Modelling Instruction perlu persiapan yang matang, dan (2) Pembelajaran Modelling instruction diharapkan dapat dilakukan beberapa kali guna meningkatkan kreatifitas dan menguatkan sikap kolaboratif antar siswa.

\section{Daftar Pustaka}

Abdul Majid. (2014). Pembelajaran Tematik Terpadu. Bandung: Remaja Rosdakarya.

Firdaus. (2009). Upaya Peningkatan Hasil Belajar Matematika Siswa Melalui Penerapan odel Pembelajaran ARIAS Pada Materi Bentuk Pangkat, Sksr, dan Logaritma Di elas X SMAN 4 Bengkulu. Skripsi. Universitas Bengkulu.

Hake, R. (1999). Analyzing Change/ Gain Score. Indiana: Indiana University.

Harni, H. (2021). Penerapan Model Pembelajaran Inkuiri untuk Meningkatkan Motivasi dan Hasil Belajar Siswa pada Materi Cahaya dan Sifat-Sifatnya di SD Negeri 2 Uebone. Jurnal Paedagogy, 8(2), 181-189. doi:https://doi.org/10.33394/jp.v8i2.3481

Majid, A. (2014). Strategi Pembelajaran. Bandung: PT Remaja Rosdakarya.

Megowan-Romanowicz, C. (2016). What Is Modeling Instruction? NSTA Reports, 3.

Nahak, R., \& Bulu, V. (2020). Efektivitas Model Pembelajaran Inkuiri Terbimbing Berbantu Lembar Kerja Siswa Berbasis Saintifik Terhadap Hasil Belajar Siswa. Jurnal Kependidikan: Jurnal Hasil Penelitian dan Kajian Kepustakaan di Bidang Pendidikan, Pengajaran dan Pembelajaran, 6(2), 230-237. doi:https://doi.org/10.33394/jk.v6i2.2369

Nasiroh, D. (2021). Peningkatan Keterampilan Proses Sains Melalui Model Inkuiri Terbimbing bagi Siswa SD Negeri 1 Pingit Kabupaten Temanggung Jawa Tengah. Jurnal Paedagogy, 8(3), 447-453. doi:https://doi.org/10.33394/jp.v8i3.3904 Nasution, N dkk. (1998). Pendidikan IPA. Jakarta : Universitas Terbuka.

Nurkhasanah, S. (2019). Penerapan Model Pembelajaran Inkuiri untuk Meningkatan Aktifitas Belajar Siswa pada Mata Pelajaran Ilmu Pengetahuan Alam Kelas IX.A SMP Negeri 1 Gangga. Jurnal Kependidikan: Jurnal Hasil Penelitian dan Kajian Kepustakaan di Bidang Pendidikan, Pengajaran dan Pembelajaran, 5(1), 47-53. doi:https://doi.org/10.33394/jk.v5i1.1393

Sanita, R., \& Anugraheni, I. (2020). Meta Analisis Model Pembelajaran Inquiry untuk Meningkatkan Hasil Belajar Siswa Sekolah Dasar. Jurnal Kependidikan: Jurnal 
Hasil Penelitian dan Kajian Kepustakaan di Bidang Pendidikan, Pengajaran dan Pembelajaran, 6(3), 567-577. doi:https://doi.org/10.33394/jk.v6i3.2949

Sanjaya Wina. (2006). Strategi Pembelajaran Berorientasi Standar Proses Pendidikan. Rawamangun-Jakarta: Kencana Perdana Media Group.

Soekarman, S. (2021). Impementasi Pembelajaran Fisika Pokok Bahasan Elastisitas Melalui Inquiry Based Learning di SMA Negeri 2 Donggo. Jurnal Paedagogy, 8(2), 197209. doi:https://doi.org/10.33394/jp.v8i2.3521

Sudjana, Nana. (2002). Dasar-Dasar Proses Belajar Mengajar. Bandung : Sinar Baru Algesindo. 